\title{
Size-class structure of the forests of Finland during 1921-2013: a recovery from centuries of exploitation, guided by forest policies
}

\author{
Helena M. Henttonen ${ }^{1} \cdot$ Pekka Nöjd $^{2} \cdot$ Susanne Suvanto $^{1}$ (D) $\cdot J^{\text {Juha Heikkinen }}{ }^{1}$ (D) $\cdot$ Harri Mäkinen $^{2}$ (D)
}

Received: 28 May 2019 / Revised: 20 September 2019 / Accepted: 18 November 2019 / Published online: 27 November 2019

(c) The Author(s) 2019

\begin{abstract}
Frequency distributions of tree diameters are a powerful tool for analyzing changes of tree populations in large areas. We analyzed the densities and mean volume estimates of trees in different size classes for the Finnish forests over the time-span of the National Forest Inventories (1921-2013). The results display a general increase in trees in all size classes, species group and geographical area, mainly after the 1970s. The densities of medium- and large-sized conifers showed large increases in the southern boreal subzone, spruces even more than pines. Small- to medium-sized pines have increased in the middle and northern boreal subzones. The shifts in growing stock are related to changing land use, resulting from the development of the society. The low quantities of both growing stock and large trees during the 1920s reflect a poor initial state of forests. Several land use forms of the former agriculture-based society were detrimental to forests, including slash and burn agriculture, cattle grazing and tar production. The pressure from alternative land use forms was stronger in southern Finland, where the population density (people per $\mathrm{km}^{2}$ ) is much higher. Between 1971 and 2013, the changes in size-class structure can be attributed mainly to intensified silviculture boosted by actions of the Finnish governments, including both legislation and financial support for management activities. Not only the development of growing stock has exceeded expectations, but the increase has also concentrated in the economically valuable trees in the large size classes.
\end{abstract}

Keywords Tree density $\cdot$ Frequency distribution of tree diameters $\cdot$ Land use $\cdot$ Forest inventory $\cdot$ Boreal forests

Communicated by Martin Moog.

Electronic supplementary material The online version of this article (https://doi.org/10.1007/s10342-019-01241-y) contains supplementary material, which is available to authorized users.

Harri Mäkinen

harri.makinen@luke.fi

Helena M. Henttonen

helena.henttonen@luke.fi

Pekka Nöjd

pekka.nojd@luke.fi

Susanne Suvanto

susanne.suvanto@luke.fi

Juha Heikkinen

juha.heikkinen@luke.fi

1 Natural Resources Institute Finland (Luke), PO Box 2, 00791 Helsinki, Finland

2 Natural Resources Institute Finland (Luke), Luke, Tietotie 2, 02150 Espoo, Finland

\section{Introduction}

The global forest area has been declining during 1990-2015 according to the UN FAO Global Forest Resources Assessments (FRA), but the annual rate of net forest loss halved from 7.3 $\mathrm{M}$ ha a ${ }^{-1}$ in the 1990 s to $3.3 \mathrm{M} \mathrm{ha} \mathrm{a}^{-1}$ during 2010-2015, with slowing deforestation, increased humaninduced afforestation and natural expansion of forests contributing to the development (Keenan et al. 2015). Forest areas have been stable or expanding in the temperate and boreal regions, but deforestation continues in the tropics (Keenan et al. 2015). Especially large reductions of both forest area and growing stock have been reported for southern America and western and southern Africa. According to the FRA, the global growing stock decreased slightly between the years 1990-2000, but has increased thereafter (Köhl et al. 2015). Conflicting estimates about the effects of forests on the global carbon budget have been reported (cf. Pan et al. 2011; Kauppi et al. 2015; Köhl et al. 2015). In any case, the forests of the developed countries generally constitute a vital carbon sink (Köhl et al. 2015). 
Sample-based national forest inventories (NFIs) and forest development scenarios based on inventory data are key tools in planning national forest policies and forest utilization, including investment plans for forest industries (Tomppo et al. 2010). NFIs have become common in recent decades, but their coverage is still low in the developing countries (Saket et al. 2010; MacDicken et al. 2015). There is still a great deal of variation in NFI features (e.g., definitions of variables, sampling designs, sample plot configurations, measurement and estimation methods), despite the recent harmonization efforts (Lawrence et al. 2010; Chirici et al. 2011).

Threat of deforestation and availability of roundwood for different forms of wood use were the primary motivation for the early NFIs. Today, the expected ecosystem services from forests are diverse, including global issues like carbon storage and biodiversity protection. Remote sensing techniques provide a means for assessing the development of forests coverage in regions, where field plots located using probability sampling are lacking (e.g., Saket et al. 2010; MacDicken et al. 2015; Crowther et al. 2015; Crespo Cuaresma et al. 2017). Currently, field measurements are still needed for producing detailed information about the structure of forests, a key to analyzing the availability of the different ecosystem services.

Frequency distributions of tree diameters are commonly used for describing tree populations. They provide direct information about the quantities of roundwood available for specific purposes. They are also useful in valuing forests,

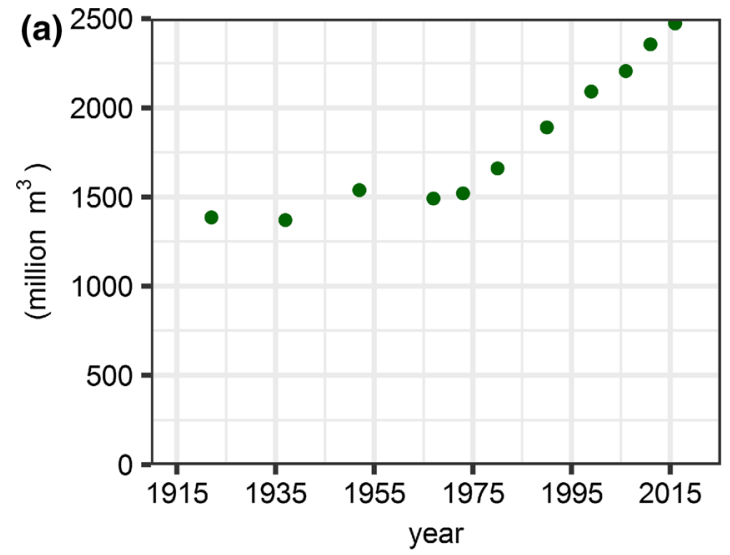

Fig. 1 Growing stock volume (a), annual increment (increment estimates for NFI1 were calculated in accordance with the present borders of Finland), annual drain [the drain in 1917-1944 describes the forest area of Finland before World War II (about 12\% larger than predicting forest growth and in management planning and assessing biomass stocks and past disturbances (Coomes and Allen 2007). At species level, diameter distributions can be used for assessing species-specific demographic rates and population trends (Wright et al. 2003).

The first sample-based forest inventories at national scale were established in the Nordic countries during the years 1919-1923 (Chirici et al. 2011; Kangas et al. 2018). The motivation for the early inventories was a concern about the adequacy of forest resources for industrial use, threatened by over-exploitation and competing forms of land use, which both resulted in small growing stocks and, consequently, reduced wood production potential.

The Nordic countries provide examples of rapidly rising trends in growing stock and annual growth, common for developed countries in general (Kauppi et al. 2018). We analyzed in detail the tree-size structure of the forests of Finland, the country with the largest forest area per capita in Europe (Palo and Lehto 2012). Like growing stock and annual growth also the annual drain, which includes removal by cuttings and mortality, has shown a rising trend in Finland, currently exceeding the level of annual growth of the 1920 s by more than $50 \%$ (Fig. 1). Before the 1950s, a large share of wood consumption was non-industrial wood, which mainly consisted of domestic fuelwood in small-scale housing (e.g., Saari 1934; Sevola 1988). During the same period, the change in the combined area of forest land and poorly productive forest land has been 1.6\% (Korhonen et al. 2017, for details see Discussion).

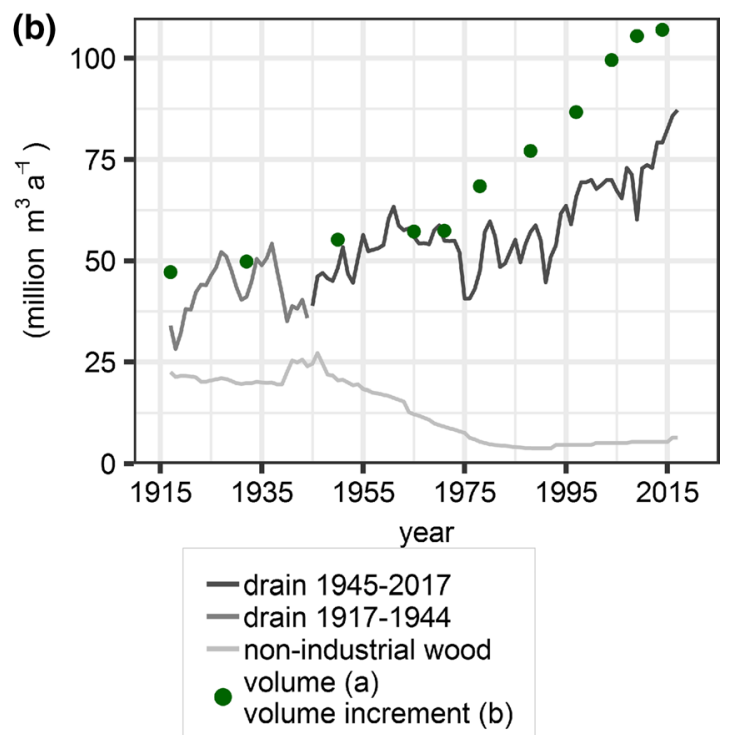

present)] and the consumption of domestic non-industrial wood (b) in Finland during 1917-2017 (Finnish forest statistics, 2018; www.stat. fi/tup/satavuotias-suomi/vuosisadan-lahteet.html) 
The increases in growing stock and annual growth have been attributed mainly to efficient silviculture (e.g., Kuuluvainen et al. 2012), even though environmental changes have promoted tree growth in recent decades (Henttonen et al. 2017). The change in silviculture has been promoted by actions of the Finnish governments, including both legislation and financial support for management activities (Palo and Lehto 2012). Especially influential was the transition from selective dimensional cuttings to thinning from below and clear cuts followed by immediate regeneration (Lundqvist 2017). In addition, the large-scale drainage of peatlands (5.7 million ha), equaling $60 \%$ of peatland area (Minkkinen et al. 2002) and 22\% of the current forestry land (Korhonen et al. 2017), has increased forest growth (Hökkä et al. 2002).

The shift in growing stock has also been related to changing land use, resulting from the development of the society. In 1920 and 1950, 84\% and 74\% of population lived in rural areas (Koskinen et al. 1994). The share of persons working in agriculture and forestry was 70\% and $46 \%$ in 1920 and 1950, respectively (Central Statistical Office of Finland 1979). During the 1960s and 1970s, migration into towns and population centers increased rapidly, and in 2017 only $4 \%$ were employed in agriculture and forestry (Statistics Finland 2018). Dairy farming was the most important branch of agriculture during the early part of the twentieth century (Hjerppe 1989). It was associated with a special type of land use, cattle crazing in forests over the summer season, negatively affecting forest productivity (Ilvessalo 1927; Leikola 1998).

We analyzed the changes in the tree size-class structure of the forests in Finland during 1921-2013. Tree densities and mean volume estimates for 2-cm-diameter classes are reported for tree species groups and for the three subzones of the boreal biogeographical zone. Some of the results are provided in finer geographical detail using the 21 biogeographical provinces in Finland. The affecting factors behind the observed changes are discussed paying special attention to changing land use. These types of studies are rare at national level, and the exceptionally long monitoring period makes the results unique.

\section{Materials and methods}

We estimated tree densities (stems per hectare) and mean growing stock volumes $\left(\mathrm{m}^{3} \mathrm{ha}^{-1}\right)$ by tree diameter $(d b h)$ class and tree species group using the Finnish NFI data from the 1920s (NFI1), from the 1970s (NFI6) and the 2010s (NFI11). Only living trees are reported, as dead trees have not been monitored in a consistent fashion throughout the study period. Three tree species groups were used: Scots pine (Pinus sylvestris L.) (currently 50\% of growing stock in
Finland, includes the very small densities of conifers other than Norway spruce), Norway spruce (Picea abies (L.) Karst.) (30\%) and broadleaved tree species (Korhonen et al. 2017). In Finland, broadleaves consist mainly of two birch species, aspen and two alder species, with total of $20 \%$ of the growing stock (Korhonen et al. 2017): Betula pubescens Ehrh. (12\%), Betula pendula Roth (5\%), Populus tremula L. (2\%) and Alnus incana (L.) Moench and Alnus glutinosa (L.) Gaertn. (1\%).

We applied the estimation methods of the Finnish NFIs, presented in detail in Lindeberg (1924) (NFI1, line survey sampling errors), Ilvessalo (1927) (NFI1, line survey) and Tomppo et al. (2011) (angle count plot inventory) (for details, see Henttonen et al. 2019). Sampling errors were estimated for the tree density estimates in NFI1 and NFI11. Sampling errors for the change in tree density between NFI1 and NFI11 were estimated assuming independence between the two inventories, i.e., the variance of the change in tree density was calculated as the sum of the variances for NFI1 and NFI11.

\section{Sampling design and measurements in the Finnish NFIs}

The development of the Finnish NFI from the 1920s to the early 2000s is described in Tomppo et al. (2011). Only the most important details and changes related to the assessment of the frequency distributions of tree diameters are summarized here.

\section{NFI1 (1921-1924)}

The sample of NFI1 (1921-1924) consisted of inventory lines oriented from southwest to northeast with $26 \mathrm{~km}$ distance between subsequent lines in most parts of the country (Ilvessalo 1927). Land use and site characteristics were assessed visually for each land figure and forest stand intersected by the inventory line. Stand volumes (per ha) were estimated visually. These estimates were calibrated using sample plot measurements. The sample plots were $10 \mathrm{~m} \times 50 \mathrm{~m}$ line strips located at the end of each $2000 \mathrm{~m}$ of the inventory line. In case the plot was not entirely within a single forest stand, it was shifted so that it did fit into a single stand. For small stands, it was possible to measure plots shorter in length than $50 \mathrm{~m}$. On the sample plots, the $d b h$ of each tree was measured and registered in $2-\mathrm{cm}$ classes $(0-2 \mathrm{~cm}, 2-4 \mathrm{~cm}, \ldots)$. For trees forked (split into several stems) below $1.3 \mathrm{~m}, d b h$ was measured separately for each stem. Some of the field crews of NFI1 had not registered stems with a $d b h$ smaller than $4 \mathrm{~cm}$. We therefore do not provide results for trees smaller than $4 \mathrm{~cm}$ at breast height.

The definition of forest land was based on a visual classification describing site productivity (Ilvessalo 1927). Forest 
land was divided into two main categories: productive forest land and forest land of poor growth potential. On forest land, also the use for cattle grazing as well as tracks of slash and burn cultivation were recorded.

\section{NFI6 (1971-1976) and NFI11 (2009-2013)}

In NFI6, trees were selected using angle count sampling (Bitterlich 1948, basal area factors in Table 1). Tree $d b h$ s were registered in $1-\mathrm{cm}$ classes $(2.5-3.5 \mathrm{~cm}, 3.5-4.5 \mathrm{~cm}$, ...). Trees with a $d b h$ below $2.5 \mathrm{~cm}$ were not measured in NFI6. In NFI11, the angle count plots were restricted to a maximum radius, which varied in the different parts of Finland (Table 1). The $d b h$ s of all trees taller than $1.35 \mathrm{~m}$ were measured with an accuracy of $1 \mathrm{~mm}$. In NFI11, $d b h$ was measured separately for each stem, if a tree was forked (split into several stems) below the height of $1.3 \mathrm{~m}$. In NFI6, the $d b h$ for forked trees was calculated as a square root of the sum of $d b h^{2}$ s of the stems. Due to forked trees, the terms "number of stems" and "stem density" would be more precise, but for simplicity we prefer to use "number of trees" and "tree density."

The techniques and accuracy of measurements have undergone several changes during the monitoring period. We report frequency distributions of tree diameters using the 2-cm $d b h$ classes applied in NFI1, and harmonized the data from later inventories accordingly (for details, see Henttonen et al. 2019). The volume models of Laasasenaho (1982) were used in the estimation of growing stock volumes for all data sets. For NFI6-NFI11, we used data from forest land and poorly productive forest land (Tomppo et al. 2011). In NFI1, the terms productive forest land and forest land of poor growth were used (Ilvessalo 1927).

\section{Biogeographical zones and subzones}

Most of the area of Finland belongs to the three subzones of the boreal biogeographical zone: southern boreal, middle boreal and northern boreal (Fig. 2) (Ahti et al. 1968). Small parts of southernmost Finland belong to the hemiboreal subzone, which is part of the temperate zone, but these were merged into the southern boreal subzone.

We calculated forest areas, tree densities and growing stock volumes for each of the three boreal subzones in NFI1 (1921-1924), NFI6 (1971-1976) and NFI11 (2009-2013). The area and growing stock volume of forest land used for cattle crazing were estimated in NFI1. The NFI1 and NFI11 sampling errors for tree densities were estimated in 2-cm $d b h$ classes and using four wide $d b h$ classes $(4-10 \mathrm{~cm}$, $10-20 \mathrm{~cm}, 20-30,>30 \mathrm{~cm})$. We constructed $95 \%$ confidence intervals for the estimated changes of tree densities from
Table 1 Sample plot type and size, the number of sample plots in forest and the number of sample trees in boreal subzones in NFI1 (1921-1924), NFI6 (1971-1976) and NFI11 (2009-2013)

\begin{tabular}{|c|c|c|c|}
\hline Inventory & Sample plot type and size & Sample plots & $\begin{array}{l}\text { Sample trees } \\
d b h \geq 4 \mathrm{~cm}\end{array}$ \\
\hline \multicolumn{4}{|c|}{ SOUTH (hemiboreal and southern boreal subzones) } \\
\hline NFI1 & Fixed area $10 \mathrm{~m} \times 50 \mathrm{~m}$ & 1663 & 101,922 \\
\hline NFI6 & Angle gauge $\mathrm{BAF}=2$ & 26,537 & 173,133 \\
\hline NFI11 & $\begin{array}{l}\text { Angle gauge } \\
\mathrm{BAF}=1 \text { and } r \max =9 \mathrm{~m}^{\mathrm{a}} \\
\mathrm{BAF}=2 \text { and } r \max =12.52 \mathrm{~m}^{\mathrm{b}}\end{array}$ & 25,377 & 229,504 \\
\hline \multicolumn{4}{|c|}{ MIDDLE (middle boreal subzone) } \\
\hline NFI1 & Fixed area $10 \mathrm{~m} \times 50 \mathrm{~m}$ & 1423 & 80,347 \\
\hline NFI6 & Angle gauge $\mathrm{BAF}=2$ & 24,738 & 106,976 \\
\hline NFI11 & $\begin{array}{l}\text { Angle gauge } \\
\mathrm{BAF}=1.5 \text { and } r \max =12.45 \mathrm{~m}^{\mathrm{c}} \\
\mathrm{BAF}=2 \text { and } \operatorname{rmax}=12.52 \mathrm{~m}^{\mathrm{b}}\end{array}$ & 20,724 & 175,544 \\
\hline \multicolumn{4}{|c|}{ NORTH (northern boreal subzone) } \\
\hline NFI1 & Fixed area $10 \mathrm{~m} \times 50 \mathrm{~m}$ & 1282 & 41,663 \\
\hline NFI6 & Angle gauge $\mathrm{BAF}=2$ or $1^{\mathrm{d}}$ & 6139 & 24,560 \\
\hline NFI11 & $\begin{array}{l}\text { Angle gauge } \\
\mathrm{BAF}=1.5 \text { and } \text { rmax }=12.45 \mathrm{~m}\end{array}$ & 7500 & 51,873 \\
\hline
\end{tabular}

BAF is the basal area factor in angle gauge sampling, and rmax is the maximum plot radius

${ }^{a}$ County of Åland, temporary plots

${ }^{b}$ Southern Finland and permanent plots in the county of Åland

${ }^{\mathrm{c}}$ Northern Finland

${ }^{\mathrm{d}}$ Northernmost Finland (Enontekiö, Inari and Utsjoki), data from NFI7 in 1978 


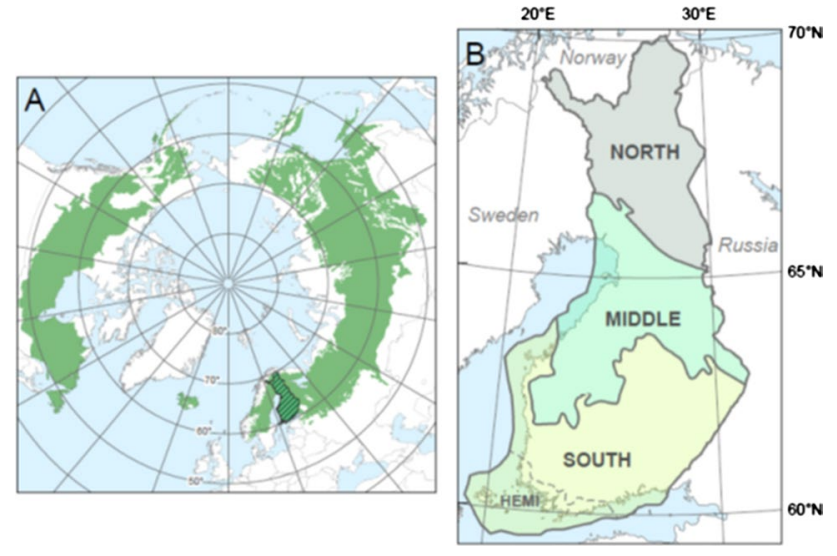

Fig. 2 The three subzones of the boreal biogeographical zone in Finland. SOUTH southern boreal (incl. HEMI hemiboreal zone), MIDDLE middle boreal, NORTH northern boreal [reprinted from Henttonen et al. (2019), Copyright (2019), with permission from Elsevier]

NFI1 to NFI1 1 for subzones $\times$ tree species $\times d b h$ classes (4-10 cm, 10-20 cm, 20-30, > $30 \mathrm{~cm}$ ).

The borders of biogeographical zones and subzones were downloaded from the service LAPIO of the Finnish Environment Institute. The NFI plots were located to these subzones using the function pnt.in.poly of R package SDMTools (VanDerWal et al. 2014).

\section{Biogeographical provinces}

The division of Finland into biogeographical provinces has been used in recording biological phenomena since the 1850s (see, e.g., Kalela (1944) for history and criticism). The present number of biogeographical provinces is 21 (Heikinheimo and Raatikainen 1981). We estimated tree densities and their changes from the 1920s to 2010s also for the biogeographical provinces using four wide $d b h$ classes $(4-10 \mathrm{~cm}, 10-20 \mathrm{~cm}, 20-30,>30 \mathrm{~cm})$ in order to assess the variation of tree densities within the boreal subzones. Also the share of forest land used for cattle crazing as well as the forest area with signs of slash and burn cultivation in 1921-1924 (NFI1) was estimated for the biogeographical provinces.

\section{Results}

\section{Tree densities in $d b h$ classes for the boreal subzones (1921-2013)}

Figures 3, 4 and 5 show the form of tree size distribution in NFI1, NFI6 and NFI11 by tree species groups and 2-cmdiameter $(d b h)$ classes for southern boreal, middle boreal and northern boreal subzones, respectively. In Table 2, the changes from NFI1 to NFI11 and their 95\% confidence intervals are presented in four wide $d b h$ classes $(4-10 \mathrm{~cm}$, 10-20 cm, 20-30, > $30 \mathrm{~cm}$ ).

Tree densities (number of trees per hectare) have increased in every region and in most $d b h$ classes during 1921-2013, but the results also highlight different developmental patterns between regions and tree species. The relative changes from the 1920s to the 1970s and from the 1970s to the 2010s expressed as percentages are shown in Supporting material 1. The mean volume estimates $\left(\mathrm{m}^{3} \mathrm{ha}^{-1}\right)$ for each diameter class are presented in Supporting material 2.

\section{Southern boreal subzone}

Changes of tree densities were limited in $d b h$ classes up to $21 \mathrm{~cm}$, except for small pines, between the 1920s and the 1970s in the south (Fig. 3). Pines and broadleaves were reduced, while spruces became slightly more common. Apart from the smallest pines, densities of pines and broadleaves in these small $d b h$ classes have recovered after the 1970s and the densities of small spruces have remained stable. Small broadleaves were-and still are-more common than either conifer species.

Tree densities in the larger size classes have increased in all species groups. Conifer densities in $d b h$ classes between $25 \mathrm{~cm}$ and $35 \mathrm{~cm}$ showed an especially large increase between the 1920s and the 1970s. Many of these trees were allowed to mature further, as the main changes in the $d b h$ classes above $35 \mathrm{~cm}$ occurred after the 1970s. Also large broadleaves have increased, especially after the 1970s, but less than conifers.

In the 1920s, medium- and large-sized pines were far more common than spruces in the southern boreal subzone, but today their densities are similar in the respective $d b h$ classes. The significant increase in spruce compared to pine and broadleaves in all size classes is also shown in Table 2.

\section{Middle boreal subzone}

The densities of small- to medium-sized pines have roughly doubled after the 1970s in the middle boreal subzone (Fig. 4). Large spruces have increased (Fig. 4), but their densities are still low compared to those in the south. Smallsized spruces in the middle boreal subzone are a solitary exception to the general increasing trend: they show a notable reduction from the 1920s to present (Fig. 4; Table 2). Densities of broadleaves declined between the 1920s and the 1970s, but have shown a recovery thereafter. 

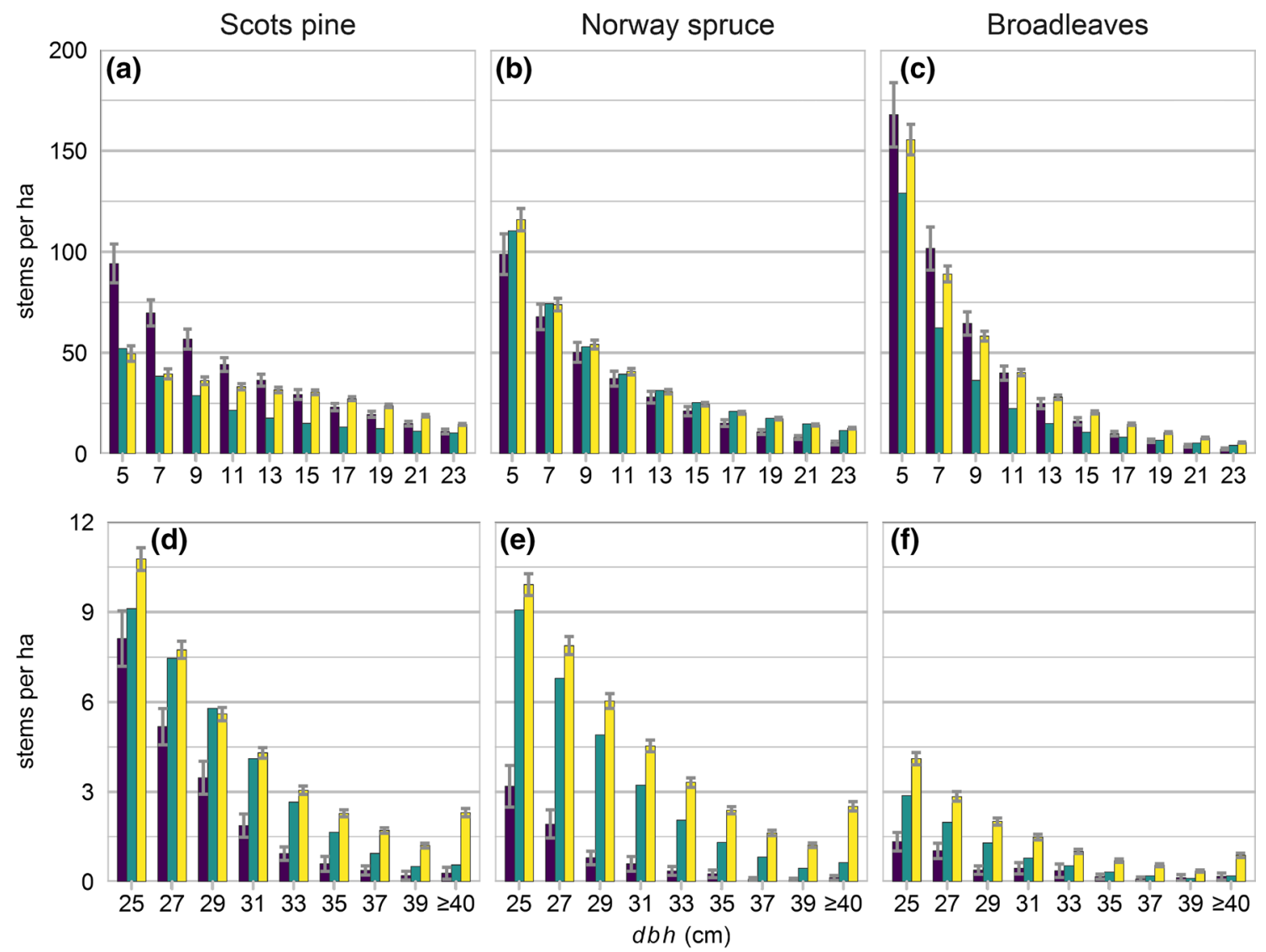

Inventory years: $1921-1924 \square$ 1971-1976, $1978 \square 2009-2013$

Fig. 3 Tree densities (stems per ha) by $d b h$ classes and tree species groups in the southern boreal subzone (incl. hemiboreal zone) in the $1920 \mathrm{~s}, 1970 \mathrm{~s}$ and 2010s. The $d b h$ classes $\leq 23 \mathrm{~cm}$ in $\mathbf{a}-\mathbf{c}$ and the $d b h$

\section{Northern boreal subzone}

The densities of small- to medium-sized pines have more than doubled also in the northern boreal subzone. The densities of spruces and broadleaves were reduced between the 1920s and the 1970s, but have recovered since then (Fig. 5). Apart from the small broadleaves, there are no significant increases since the 1920s (Table 2).

To summarize, two especially notable trends emerge, both mainly after the 1970s:

1. The densities of medium- and large-sized conifers show very large increases in the southern boreal subzone, spruces even more than pines.

2. The densities of small- to medium-sized pines and small broadleaves have increased in the middle and northern boreal subzones. classes $\geq 25 \mathrm{~cm}$ in $\mathbf{d}-\mathbf{f}$. Note the different scales for $y$-axis in $\mathbf{a}-\mathbf{c}$ and d-f. Error bars indicate $2 \times$ sampling errors

\section{Tree densities in $d b h$ classes in the biogeographical provinces}

Dividing the country into the three subzones of the boreal zone provides a somewhat crude overview of the tree populations, as each subzone includes regions with rather different historical patterns of land use. To analyze the development of tree densities in Finland in more detail, we calculated the densities of trees in 1921-1924 and 2009-2013 for the 21 biogeographical provinces in Finland using the wider $d b h$ classes of $4-10 \mathrm{~cm}, 10-20 \mathrm{~cm}, 20-30 \mathrm{~cm}$ and $>30 \mathrm{~cm}$. The change estimates from 1921-1924 to 2009-2013 were also calculated.

For small trees (Fig. 6), the largest changes were observed for pine, but the pattern has been diverse. Small pines have declined in many southern provinces. Pines between 10 and $20 \mathrm{~cm}$ have increased at the coastal region 

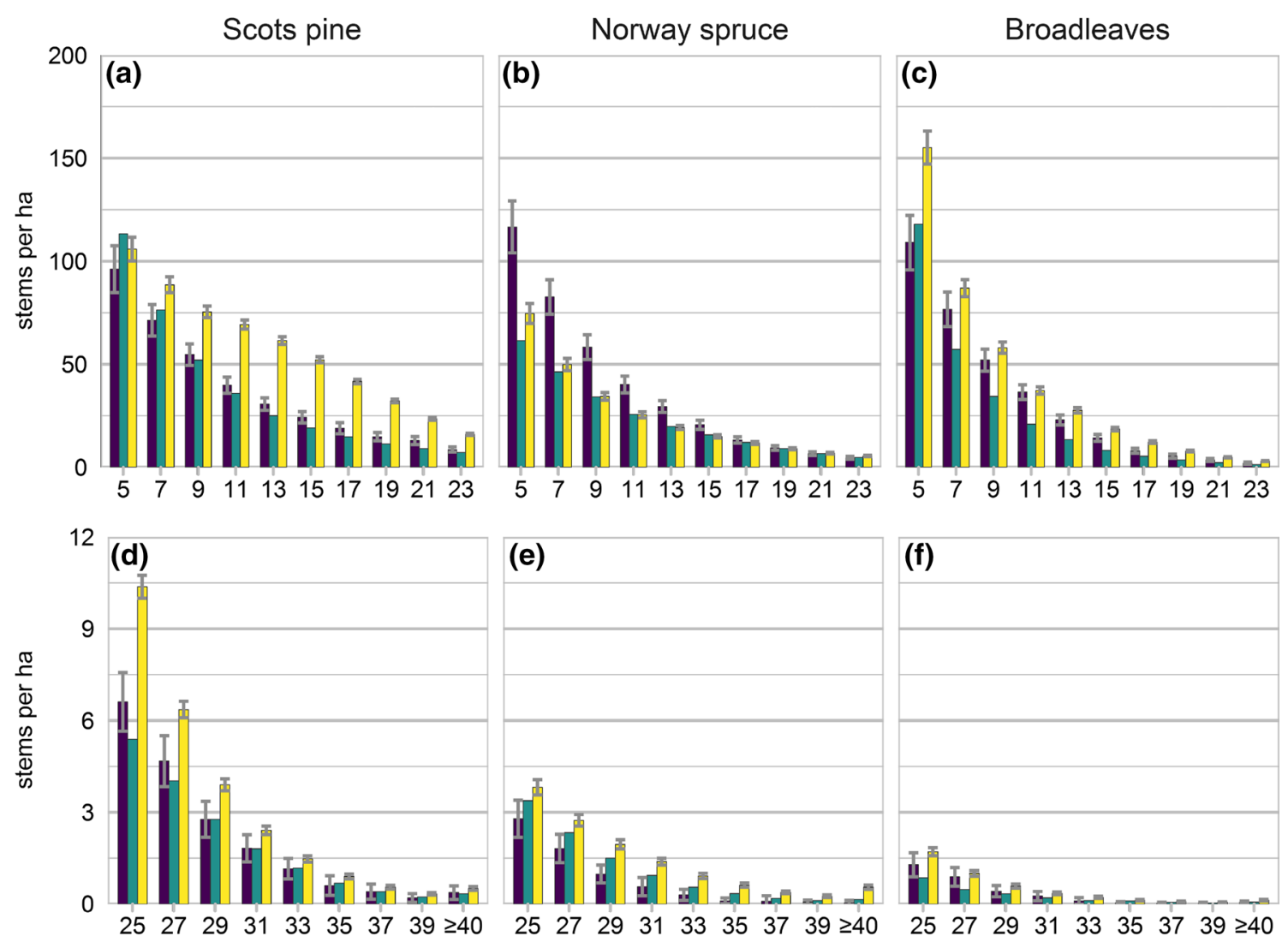

(e)

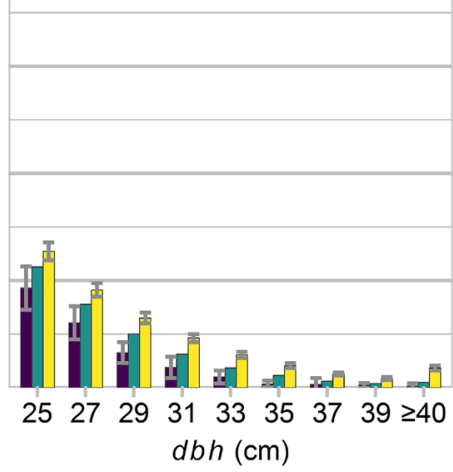

(f)

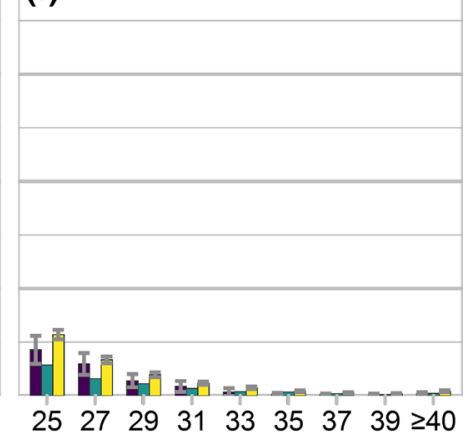

Inventory years:

$1921-1924$

$1971-1976,1978$

$2009-2013$

Fig. 4 Tree densities (stems per ha) by $d b h$ classes and tree species groups in the middle boreal subzone in the 1920s, 1970s and 2010s. The $d b h$ classes $\leq 23 \mathrm{~cm}$ in $\mathbf{a}-\mathbf{c}$ and the $d b h$ classes $\geq 25 \mathrm{~cm}$ in $\mathbf{d}-\mathbf{f}$.

in western Finland, where ditched peatlands are common. In the northern half of the country, a systematic and sizable increase has been observed.

Small spruces have declined in some southernmost provinces, and also in a couple of eastern ones in the middle part of the country (Fig. 6). An increase has occurred in a few provinces in the middle part of southern Finland.

Small broadleaves have declined in two eastern provinces in southern Finland (Fig. 6). The coastal provinces mostly show small increases.

Large trees (Fig. 7) show a heavy increase of conifers in nearly all southern provinces. In northern Finland, there are several provinces with reduced densities of large pines and spruces. Notable increases of pine were observed for the northernmost provinces. Broadleaves mostly show little change, with modest increases in some southern provinces.
Note the different scales for $y$-axis in $\mathbf{a}-\mathbf{c}$ and $\mathbf{d}-\mathbf{f}$. Error bars indicate $2 \times$ sampling errors

\section{Forest pastures}

Figure 8, describing the share of pastures of forest land, produces a pattern notably similar to the density changes of small $(4-10 \mathrm{~cm})$ broadleaves in Fig. 6. The sites used for grazing were on average fertile (Table 3). This, together with the low stocking of the pastures (Table 3), favored small broadleaves. Today, cattle grazing in forests virtually does not exist. The abandoned pastures have been taken over mainly by spruce (Figs. 6, 7).

Slash and burn agriculture had already mostly vanished in Finland by the 1920s (Heikinheimo 1915). Some signs of it were still observed in the eastern part of southern Finland, in the same geographical regions and forest site types, where cattle grazing used to be most common. For individual provinces, the largest share of slash and burn sites on forest land was $3.7 \%$ during the $1920 \mathrm{~s}$. 

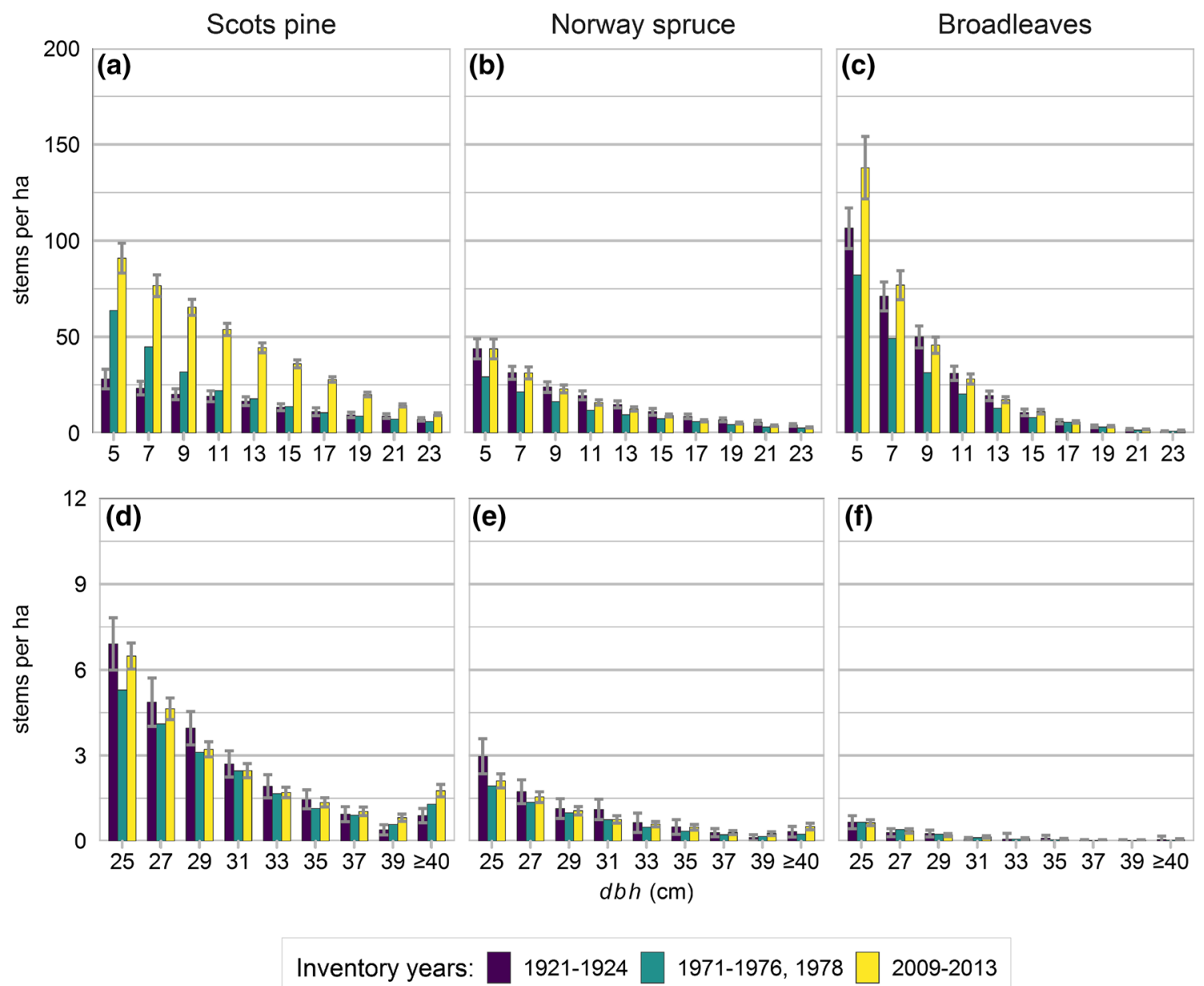

Fig. 5 Tree densities (stems per ha) by $d b h$ classes and tree species groups in the northern boreal subzone in the 1920s, 1970s and 2010s. The $d b h$ classes $\leq 23 \mathrm{~cm}$ in $\mathbf{a}-\mathbf{c}$ and the $d b h$ classes $\geq 25 \mathrm{~cm}$ in $\mathbf{d}-\mathbf{f}$.

\section{Discussion}

With few exceptions, our results display a general increase of trees in all size classes in each species group and geographical area. The most notable increases were shown by large conifers in the south and small- to medium-sized pines in the middle and northern boreal subzones. In general, larger changes have occurred in southern Finland. As studies analyzing the density of large trees in old-growth forests in Scandinavia (e.g., Nilsson et al. 2002; Jönsson et al. 2009) have reported densities higher than those observed in the recent Finnish NFIs, it is justifiable to use the term recovery.

Our study covers NFI data from the 1920s to the 2010s. The techniques and accuracy of measurements have undergone changes during this period. We reported therefore the tree densities in 2-cm $d b h$ classes and omitted dead trees and trees with $d b h$ below $4 \mathrm{~cm}$. In Finland, tree measurements were made on sample plots already in NFI1. The method thus deviated from the early inventories in Norway and Sweden, where trees were
Note the different scales for $y$-axis in $\mathbf{a}-\mathbf{c}$ and $\mathbf{d}-\mathbf{f}$. Error bars indicate $2 \times$ sampling errors

measured along entire strips, a method vulnerable to errors caused by boundary trees (Ilvessalo 1927, p. 27).

The definitions of land use classes have changed. To monitor the changes of forest area, we used the data on forest land and poorly productive forest land for NFI6 and NFI1 1 (Tomppo et al. 2011). In NFI1, the terms productive forest land and forest land of poor growth were in use (Ilvessalo 1927). For the whole country, the combined area of the two categories has increased by $1.6 \%$ between NFI1 and NFI11. A decrease of $0.3 \%$ and $3.8 \%$ was observed for southern and northern boreal subzones, respectively. In the middle boreal subzone, where ditched peatlands are common, the forest area has increased by $8.4 \%$.

\section{Factors affecting the forests of Finland before and during the study period}

Prior to the time of NFIs, the forests of Finland had been utilized intensively for centuries (Helander 1949; Tasanen 
Table 2 The changes in tree densities (stems per hectare) from the 1920s (NFI1) to the 2010s (NFI11) in the boreal subzones

\begin{tabular}{|c|c|c|c|c|}
\hline \multirow[t]{3}{*}{ Tree species group } & \multicolumn{4}{|l|}{$d b h, \mathrm{~cm}$} \\
\hline & $4-10$ & $10-20$ & $20-30$ & $>30$ \\
\hline & \multicolumn{4}{|c|}{ Stems per hectare, NFI11-NFI1 } \\
\hline \multicolumn{5}{|c|}{ SOUTH (hemiboreal + southern boreal subzone) } \\
\hline Scots pine & $\begin{array}{l}-95.4 \\
(-115.0,-75.8)\end{array}$ & $\begin{array}{l}-6.3 \\
(-16.9,4.3)\end{array}$ & $\begin{array}{l}14.7 \\
(11.3,18.1)\end{array}$ & $\begin{array}{l}10.6 \\
(9.7,11.5)\end{array}$ \\
\hline Norway spruce & $\begin{array}{l}27.0 \\
(6.0,48.0)\end{array}$ & $\begin{array}{l}21.3 \\
(11.0,31.6)\end{array}$ & $\begin{array}{l}31.5 \\
(28.7,34.2)\end{array}$ & $\begin{array}{l}14.1 \\
(13.4,14.8)\end{array}$ \\
\hline Broadleaved sp. & $\begin{array}{l}-31.2 \\
(-62.5,0.1)\end{array}$ & $\begin{array}{l}16.7 \\
(8.3,25.0)\end{array}$ & $\begin{array}{l}13.3 \\
(11.9,14.7)\end{array}$ & $\begin{array}{l}3.6 \\
(3.1,4.1)\end{array}$ \\
\hline All species & $\begin{array}{l}-99.6 \\
(-137.9,-61.3)\end{array}$ & $\begin{array}{l}31.7 \\
(17.3,46.1)\end{array}$ & $\begin{array}{l}59.4 \\
(55.6,63.3)\end{array}$ & $\begin{array}{l}28.4 \\
(27.1,29.7)\end{array}$ \\
\hline \multicolumn{5}{|c|}{ MIDDLE (middle boreal subzone) } \\
\hline Scots pine & $\begin{array}{l}48.1 \\
(23.9,72.3)\end{array}$ & $\begin{array}{l}128.2 \\
(115.2,141.2)\end{array}$ & $\begin{array}{l}24.5 \\
(19.9,29.1)\end{array}$ & $\begin{array}{l}1.6 \\
(0.7,2.5)\end{array}$ \\
\hline Norway spruce & $\begin{array}{l}-98.6 \\
(-124.9,-72.3)\end{array}$ & $\begin{array}{l}-32.6 \\
(-43.2,-22.0)\end{array}$ & $\begin{array}{l}4.0 \\
(1.6,6.4)\end{array}$ & $\begin{array}{l}2.9 \\
(2.2,3.6)\end{array}$ \\
\hline Broadleaved sp. & $\begin{array}{l}62.1 \\
(34.9,89.2)\end{array}$ & $\begin{array}{l}16.4 \\
(7.7,25.2)\end{array}$ & $\begin{array}{l}3.0 \\
(1.6,4.3)\end{array}$ & $\begin{array}{l}0.4 \\
(0.2,0.7)\end{array}$ \\
\hline All species & $\begin{array}{l}11.6 \\
(-27.2,50.4)\end{array}$ & $\begin{array}{l}112.1 \\
(99.0,125.1)\end{array}$ & $\begin{array}{l}31.5 \\
(27.2,35.7)\end{array}$ & $\begin{array}{l}5.0 \\
(3.8,6.3)\end{array}$ \\
\hline \multicolumn{5}{|c|}{ NORTH (northern boreal subzone) } \\
\hline Scots pine & $\begin{array}{l}161.4 \\
(144.7,178.0)\end{array}$ & $\begin{array}{l}112.5 \\
(101.4,123.6)\end{array}$ & $\begin{array}{l}6.9 \\
(3.4,10.3)\end{array}$ & $\begin{array}{l}0.8 \\
(-0.3,2.0)\end{array}$ \\
\hline Norway spruce & $\begin{array}{l}-1.2 \\
(-13.8,11.4)\end{array}$ & $\begin{array}{l}-11.8 \\
(-18.7,-4.8)\end{array}$ & $\begin{array}{l}-4.1 \\
(-6.5,-1.8)\end{array}$ & $\begin{array}{l}-0.1 \\
(-1.0,0.8)\end{array}$ \\
\hline Broadleaved sp. & $\begin{array}{l}32.9 \\
(1.2,64.6)\end{array}$ & $\begin{array}{l}-4.8 \\
(-13.6,3.9)\end{array}$ & $\begin{array}{l}0.2 \\
(-0.6,1.0)\end{array}$ & $\begin{array}{l}0.1 \\
(-0.2,0.4)\end{array}$ \\
\hline All species & $\begin{array}{l}193.1 \\
(152.7,233.4)\end{array}$ & $\begin{array}{l}95.9 \\
(81.5,110.3)\end{array}$ & $\begin{array}{l}2.9 \\
(-0.4,6.3)\end{array}$ & $\begin{array}{l}0.8 \\
(-0.6,2.3)\end{array}$ \\
\hline
\end{tabular}

The $95 \%$ confidence intervals in parenthesis
2004; Kuisma 2006). The small quantities of both growing stock and large trees in Finland during the 1920s reflect a poor initial state of forests-a view also clearly stated by contemporary experts (Ilvessalo 1927; Helander 1949). Based on a visual classification in NFI1, Ilvessalo (1927) reported that more than $40 \%$ of forests in southern Finland were in an 'unsatisfactory condition' and only $27 \%$ of forests reached a minimum of $80 \%$ of the growing stock of fully stocked stands. The difference between the observed densities and fully stocked stands was especially large in old stands (Ilvessalo 1927; see also Kauppi et al. 2010; Henttonen et al. 2019).

The contributing factors included both alternative forms of land use and the history of industrial wood use prior to the 1920s. Several land use forms of the traditional Finnish agriculture-based society were detrimental to forests, including slash and burn agriculture, cattle grazing and tar production. Each one of these tended to interrupt the development of trees and forest stands at an early phase, and as all three were practiced on large areas, their combined effect was severe.
The pressure from alternative land use forms was stronger in southern Finland, a region with much higher population density. Indeed, the results of NFI1 show that while the sharp climatic gradient between southern and northern Finland would suggest otherwise, large trees were more common in northern Finland during the 1920s (see also Henttonen et al. 2019). The situation has been reversed. The densities of large trees have increased greatly in the south. In the north, the rate of change has been inconsistent, some provinces even showing a clear reduction of large trees.

Forest fires were also more common in the past. Wallenius (2011) reported that during 1850-1950 annually burned forest areas in central Fennoscandia diminished to less than $10 \%$ of the level of prior centuries. He concludes that the formerly common forest fires had mainly been caused by humans as the traditional livelihoods were associated with high fire use frequency. Slash and burn agriculture used to be a particularly common cause of uncontrolled forest fires (Helander 1949).

Before the 1850s, the market value of roundwood was low. This led to a situation, where other forms of land use 


$\begin{array}{llllll}\text { dbh } 4-10 \mathrm{~cm} & \mathrm{dbh} 4-10 \mathrm{~cm} & \begin{array}{l}\text { dbh } 4-10 \mathrm{~cm} \\ \text { Change }\end{array} & \text { dbh } 10-20 \mathrm{~cm} & \mathrm{dbh} 10-20 \mathrm{~cm} & \begin{array}{l}\mathrm{dbh} 10-20 \mathrm{~cm} \\ \text { Change }\end{array} \\ \text { Stems/ha } & \text { Stems/ha } & \text { from 1921-1924 } & \text { Stems/ha } & \text { Stems/ha } & \text { from 1921-1924 } \\ 1921-1924 & 2009-2013 & \text { to } 2009-2013 & 1921-1924 & 2009-2013 & \text { to 2009-2013 }\end{array}$
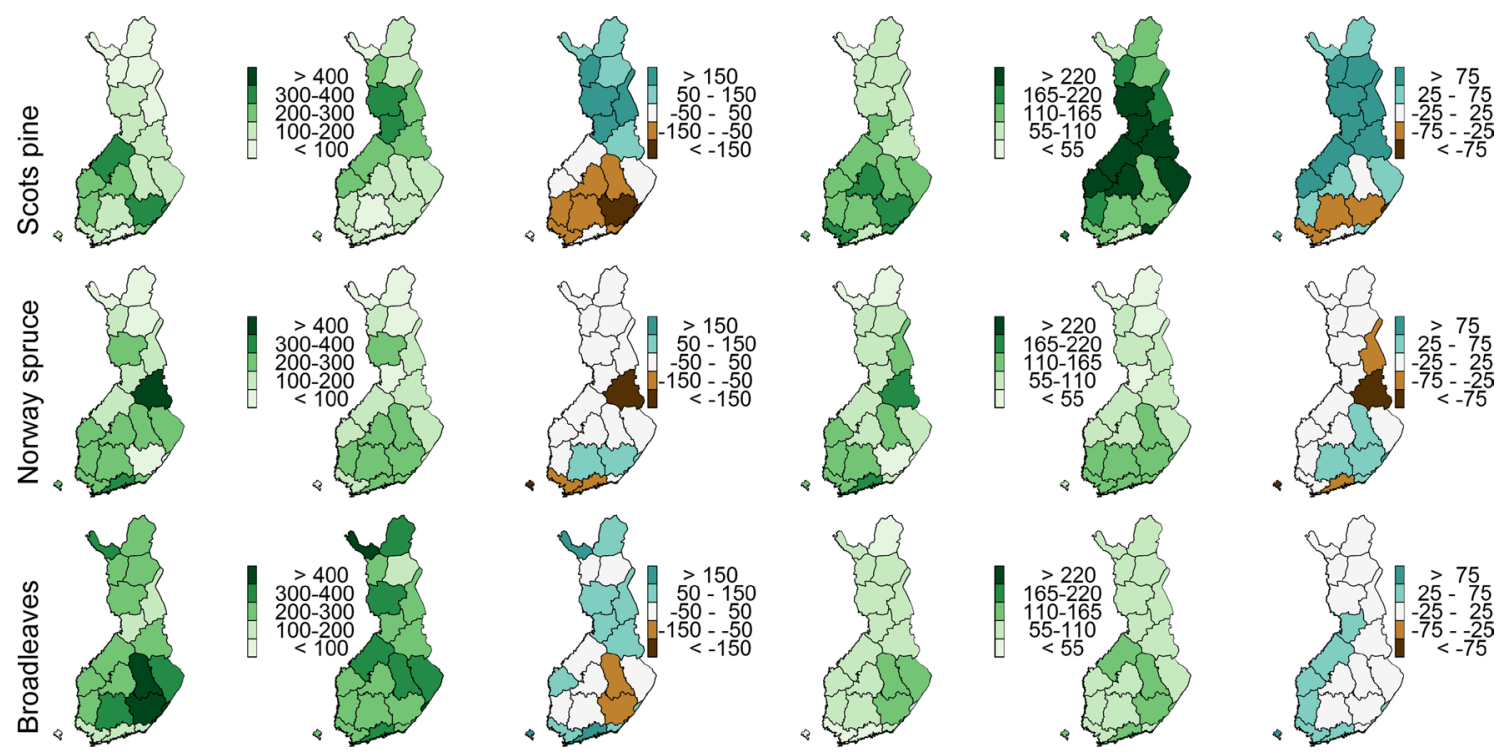

Fig. 6 The densities of trees $d b h$ 4-10 cm and 10-20 cm in 1921-1924 and in 2009-2013 and the change of the densities, presented for tree species groups and the biogeographical provinces

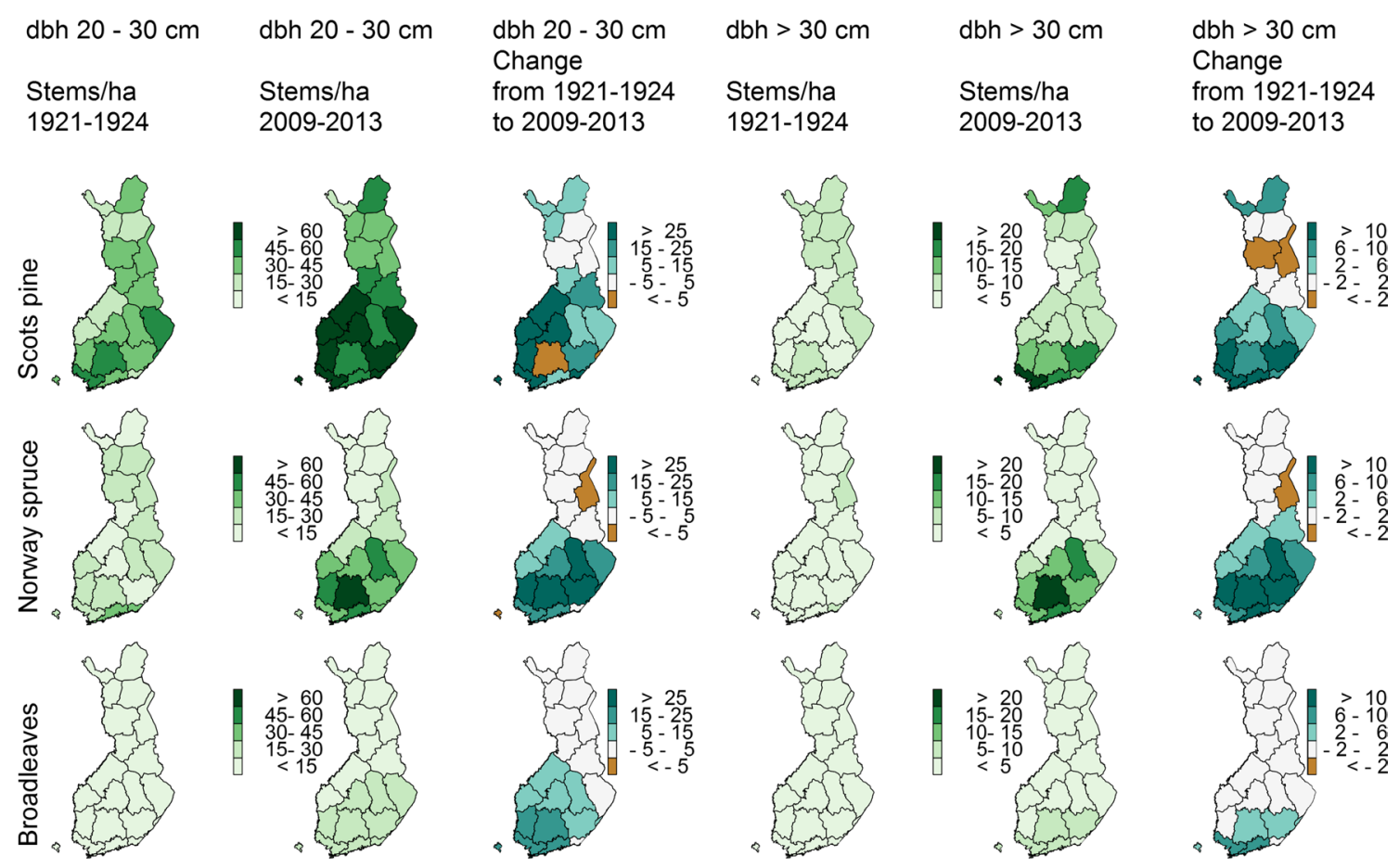

Fig. 7 The densities of trees $d b h$ 20-30 cm and $>30 \mathrm{~cm}$ in 1921-1924 and in 2009-2013 and the change of the densities, presented for tree species groups and the biogeographical provinces 


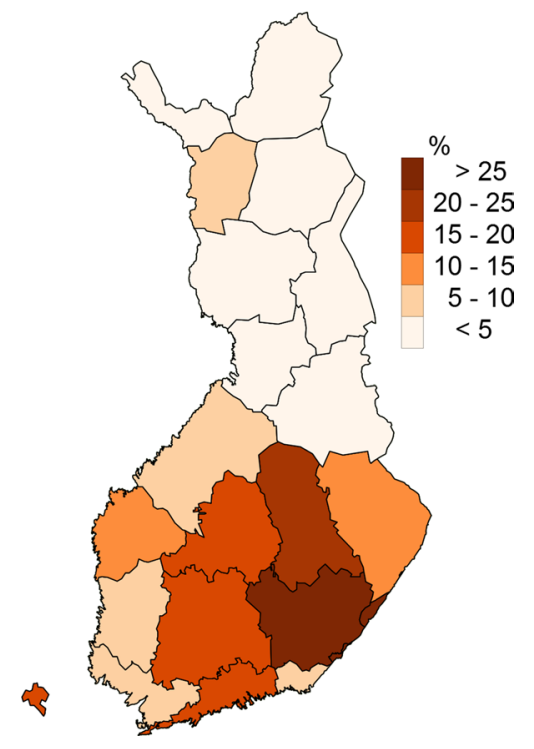

Fig. 8 The share of forest land used for cattle grazing in 1921-1924

were more attractive to the forest owner (Palo and Uusivuori 1999; Kuisma 2013). Also, considerable shares of forests were owned by the state and local communities, which did not efficiently control unauthorized use of trees, further encouraging destructive use of forest resources (Tasanen 2004). This type of situation still exists in some countries, where weak governance in combination with new infrastructure and pressure from growing population may lead to deforestation (e.g., Laurance et al. 2014).

During the latter part of the nineteenth century, the saw mill industry in Finland expanded rapidly (Ahvenainen 1984). This was partly caused by technological advances, especially the use of steam engines. At the same time, lowered duties in Great Britain, the largest importer of sawnwood from Finland, and abandoning production restrictions formerly handicapping the saw mills of Finland also contributed to the development (Kuisma 2013).

The expanding saw mill industries consumed large-sized timber. Selective dimensional cuttings were used for removing the largest, best quality trees (Helander 1949), and the remaining forest stands were frequently not sufficiently dense to fully utilize the wood production potential of the site (Ilvessalo 1927). On the other hand, Palo and Uusivuori (1999) inferred that increasing forestry incomes from the saw mill industries were a key factor in the transition from the traditional forest use toward more sustainable wood production.

The consumption of fuelwood was over 13 million $\mathrm{m}^{3} \mathrm{a}^{-1}$ (stemwood) in Finland during the early twentieth century, about one-third of annual drain (Saari 1934; Sevola 1988; Myllyntaus and Mattila 2002). One could argue that as fertile sites were a desirable location for farm houses, they were probably taxed more heavily by rural fuelwood cuttings. The total consumption of stemwood for energy use in small-scale housing decreased to 3.8 million $\mathrm{m}^{3} \mathrm{a}^{-1}$ by the early $1990 \mathrm{~s}$, but started to increase thereafter. The current estimate is 6.5 million $\mathrm{m}^{3} \mathrm{a}^{-1}$ (Finnish forest statistics 2018).

Apart from the use of fuelwood, the demand for smallsized trees was limited during the nineteenth century. The market imbalance affected the structure of the tree population. The situation started to change with the gradual development of pulp and paper industries, mainly after the 1870 s (Kuisma 2006), but the low densities of large trees during the 1920s still reflected the effects of this phase in history.

After the 1920s, the growing stock and annual growth changed at a slow pace until the early 1970s. Between 1971 and 2013, the growing stock increased by 53\% and the annual volume increment by $84 \%$. These changes can be attributed mainly to intensified silviculture, described

Table 3 The share of pastures of total forest area and of total growing stock and the mean volume on fertile sites on forest pastures and forest land not used for cattle grazing in 1921-1924

\begin{tabular}{|c|c|c|c|c|c|c|}
\hline \multirow[t]{2}{*}{ Boreal subzone } & \multicolumn{2}{|c|}{ Share of pastures of forest area } & \multicolumn{2}{|c|}{ Share of pastures of total growing stock } & \multicolumn{2}{|c|}{$\begin{array}{l}\text { Mean volume on fertile sites on } \\
\text { mineral soils }\end{array}$} \\
\hline & Of all sites (\%) & $\begin{array}{l}\text { Of fertile sites on } \\
\text { mineral soils (\%) }\end{array}$ & Of all sites (\%) & $\begin{array}{l}\text { Of fertile sites on } \\
\text { mineral soils }(\%)\end{array}$ & $\begin{array}{l}\text { Forest pastures } \\
\left(\mathrm{m}^{3} \mathrm{ha}^{-1}\right)\end{array}$ & $\begin{array}{l}\text { Forests } \\
\text { not used } \\
\text { as pastures } \\
\left(\mathrm{m}^{3} \mathrm{ha}^{-1}\right)\end{array}$ \\
\hline $\mathrm{SOUTH}^{\mathrm{a}}$ & 19.4 & 29.6 & 12.9 & 17.0 & 50.6 & 103.7 \\
\hline MIDDLE $^{\mathrm{b}}$ & 7.0 & 14.8 & 4.6 & 8.9 & 51.5 & 111.3 \\
\hline NORTH $^{\mathrm{c}}$ & 2.0 & 1.0 & 1.5 & 0.8 & 58.9 & 72.3 \\
\hline
\end{tabular}

Fertile sites include the Myrtillus type (MT) and sites more fertile (Cajander 1949; Ilvessalo 1927) on mineral soils

${ }^{\text {a }}$ Southern boreal subzone (incl. hemiboreal zone)

${ }^{\mathrm{b}}$ Middle boreal subzone

${ }^{\mathrm{c}}$ Northern boreal subzone 
in detail by Kuuluvainen et al. (2012), although Henttonen et al. (2017) concluded that environmental changes explain as much as $37 \%$ of the growth increase of forests on mineral soils.

During our study period, the Finnish governments have frequently taken an active role in ensuring sufficient raw material for wood processing industries, a branch with a key role in the national economy. The instruments included both legislation prohibiting destructive forest use and subsidies promoting efficient silviculture (Palo and Uusivuori 1999). Especially influential was the ban against selective dimensional cuttings, which began to take effect in the 1950s and resulted in a transition to clear cuts in combination with artificial regeneration and thinning from below, which enhanced the growth of the remaining large trees (Siiskonen 2007; Kuuluvainen et al. 2012). The subsidized treatments included the drainage of ca. 5 million ha of peatlands, construction of a dense network of forest roads, the various phases of forest regeneration and forest fertilization.

Our results showed that tree densities and growing stock have increased in all geographical regions. There were, however, differences between species groups that can be traced back to land use patterns on the typical sites of each species.

\section{Scots pine}

Today, 50\% of growing stock consists of Scots pine in Finland (Korhonen et al. 2017). The species dominates on sites with low fertility. Until the late nineteenth century, these sites particularly in central and eastern Finland were commonly used for producing tar, which until the 1820 s produced a larger share of import revenues than any other product (Kuisma 2006). As fairly small-sized trees were used as raw material, the treatment effectively prevented pinedominated sites from developing into mature stands. Signs of tar production were still present in the 1920s (Ilvessalo 1927), as low-density pine stands were common. Pine also provided the preferred raw material for the early sawmill industries, and pine stands had been heavily taxed by selective dimensional cuttings before the beginning of our study period.

Pine is also the most common species on peatlands, which cover $29 \%$ of the area of forest land and poorly productive forest land in Finland (Korhonen et al. 2017). Peatlands are more common in the middle and northern boreal subzones in Finland, and the drainage of peatlands partly explains the rapid accumulation of small- and medium-sized pines in those subzones.

Pine has been favored in forest regeneration, especially during the 1970s and 1980s, when the species was commonly planted also on fertile sites. This led to problems with timber quality due to excessive branchiness, and the practice has been abandoned (Uusvaara 1985). The abundance of medium-sized pines in today's forests is partially due to this period in history.

\section{Norway spruce}

Norway spruce (30\% of growing stock) is an economically viable choice only for fertile sites. The densities of medium- and large-sized spruces were lower than pines during the 1920s in the southern and middle parts of Finland. Today, spruces and pines of this size are equally common. The faster recovery reflects the higher growth potential of the sites occupied by spruce, but probably also a heavier exploitation of the fertile sites by competing forms of land use prior to the 1920s.

Unlike today, spruce was rarely used by the sawmill industry during the nineteenth century. The time required for transporting raw wood to the mills used to be long, even several years. Spruce is less resistant against quality losses during transportation than pine (Ahvenainen 1984).

In the 1920s, fertile sites in the southern and middle parts of Finland were affected by two common agricultural practices, slash and burn agriculture and cattle grazing. Slash and burn agriculture consisted of drying, cutting and burning of trees, and using the cleared forest site for cultivation over one or two growing seasons. Once common on fertile forest sites, the method had been mostly abandoned by the turn of the twentieth century (Heikinheimo 1915). As typical rotation periods for spruce are 60-70 years in southern Finland, many affected sites had not yet developed into mature stands by the time of NFI1 (1921-1924).

Cattle were commonly grazed in forests. The pastures were often deliberately kept open to promote the growth of grass and hay. In the southernmost region (southern boreal + hemiboreal in Fig. 1), 19\% of forest land belonged to this group in 1921-1924. These sites were more fertile than forests on average, but the mean growing stock on pastures was $51 \mathrm{~m}^{3} \mathrm{ha}^{-1}$, quite a bit lower than the mean of those forest on similar sites not used for grazing $\left(104 \mathrm{~m}^{3} \mathrm{ha}^{-1}\right)$. Unlike slash and burn agriculture, grazing in forests remained common until the 1960s. Our results show that the densities of spruce have increased heavily on those regions, where grazing was especially common in the 1920s, while the densities of small pines and broadleaves have decreased.

By the early twentieth century, these factors had left their mark on the fertile forest sites in southern and middle parts of Finland. Abandoning these land use practicestogether with efficient silviculture-explains the especially fast increase in large spruces in southern Finland. 


\section{Broadleaves}

Broadleaves (20\% of growing stock) have shown smaller changes than the two conifer species. Like spruce, also broadleaves are more competitive on fertile soils. Many of the factors mentioned for spruce also apply for broadleaves. They were also preferred in the fuelwood cuttings (e.g., Saari 1934). The frequencies of large broadleaves have increased less than for the conifer species, largely because conifers have been favored in regeneration and thinnings (Korhonen et al. 2017). Currently, artificial regeneration using broadleaves is risky, as the moose and deer populations are high.

\section{The outlook of forests resources in Finland}

The observed development of both growing stock and the size distribution of the forests of Finland has undoubtedly fulfilled the primary goals of the Finnish forest policies of the twentieth century. Not only the development of growing stock has exceeded expectations (cf. Ilvessalo 1927; Ervasti et al. 1965; Talousneuvosto 1985), but our results demonstrate that the increase has concentrated in the economically valuable trees in the large size classes. As the annual growth has exceeded the annual drain since the 1970s, one might assume that the steady development is likely to continue. In reality, the forest sector of Finland is facing a new situation.

In November 2018, the European Commission announced a strategy toward becoming carbon neutral by the year 2050, also stating that "it is realistic to make Europe both climate neutral and prosperous" (http://europa.eu/rapid/press -release_IP-18-6543_en.html). Providing prosperity without endangering the goal of climate neutrality is also the dilemma for the forest sector in Finland. According to the Finnish greenhouse gas inventory, forests are by far the most significant carbon sink. In 2017, the net sink of greenhouse gases in forest land was 27 million tonnes of $\mathrm{CO} 2$ equivalent (incl. biomass, soil, litter and dead wood as well as $\mathrm{CH} 4$ and $\mathrm{N} 2 \mathrm{O}$ emissions from drained forest land), while the net sink of the whole land use, land use change and forestry sector (LULUCF) was 20.4 million tonnes and the total emissions of other sectors were 55.5 million tonnes (Official Statistics of Finland 2019). The difference between annual increment and fellings largely determines the net sink of the LULUCF sector.

The Finnish forest sector companies have been reporting increasingly strong financial results during the current decade, and plans for constructing several large biorefineries in Finland have been announced. Increased industrial capacity would imply higher annual drain, which would lead to a reduced carbon sequestration into forests, unless annual growth can be increased as well. The annual growth of the forests of Finland has almost doubled since the 1960s, and a further growth increase is a definite possibility (Hynynen et al. 2015). The historical development of the annual growth was boosted by actions by the Finnish government, but maintaining the upward trend in growth may be more difficult from now on, since the state of the forests has improved after the early twentieth century, after centuries of over-exploitation.

Narrowing the gap between annual growth and drain via increased industrial wood use would slow down the ongoing development of forest structure, especially the rapid increase of large-sized trees. This would be an unwelcome change from the perspective of preserving biodiversity (Hyvärinen et al. 2019) and the recreational use of forests (Mäntymaa et al. 2018). Replacing fossil fuels with renewable energy involves additional pressure for increased use of wood fuels and, consequently, forest resources. Given the fact that the role of forest industries is larger in the national economy of Finland than in any other developed country, the hot debate is likely to continue.

Acknowledgements Open access funding provided by Natural Resources Institute Finland (LUKE). The study was supported by grants from the Academy of Finland (Nos. 257641, 288267 and 315495).

Open Access This article is distributed under the terms of the Creative Commons Attribution 4.0 International License (http://creativeco mmons.org/licenses/by/4.0/), which permits unrestricted use, distribution, and reproduction in any medium, provided you give appropriate credit to the original author(s) and the source, provide a link to the Creative Commons license, and indicate if changes were made.

\section{References}

Ahti T, Hämet-Ahti L, Jalas J (1968) Vegetation zones and their sections in northwestern Europe. Ann Bot Fenn 5(3):169-211

Ahvenainen J (1984) Suomen sahateollisuuden historia. In: Finnish. Söderstrom, Porvoo, $461 \mathrm{p}$

Bitterlich W (1948) Die Winkelzählprobe. Allg Forst-und Holzwirtsch Ztg 59:4-5

Cajander AK (1949) Forest types and their significance. Acta For Fenn 56(5):1-71

Central Statistical Office of Finland (1979) Population by industry: population by industry and commune in 1880-1975. Statistical surveys 63. Valtion painatuskeskus. Helsinki, p 370. http:// www.doria.fi/handle/10024/91484. Accessed 20 May 2019

Chirici G, Winter S, McRoberts RE (eds) (2011) National Forest Inventories: contributions to forest biodiversity assessments. Springer, Dordrecht, p 206. https://doi. org/10.1007/978-94-007-0482-4

Coomes DA, Allen RB (2007) Mortality and tree-size distributions in natural mixed-age forests. J Ecol 95:27-40. https://doi.org/10.11 11/j.1365-2745.2006.01179.x

Crespo Cuaresma J, Danylo O, Fritz S, McCallum I, Obersteiner M, See L, Walsh B (2017) Economic development and forest cover: evidence from satellite data. Sci Rep 7:40678. https://doi. org/10.1038/srep40678 
Crowther TW, Glick HB, Covey KR, Bettigole C, Maynard DS, Thomas SM et al (2015) Mapping tree density at a global scale. Nature 525:201-205. https://doi.org/10.1038/nature14967

Ervasti S, Heikinheimo L, Holopainen V, Kuusela K, Sirén G (1965) The development of Finland's forests in 1964-2000. Silva Fenn 117:1-35. https://doi.org/10.14214/sf.a14282

Finnish Forest Statistics (2018) Luonnonvarakeskus (Luke). Helsinki, p 189. http://urn.fi/URN:NBN:fi-fe201902043966. Accessed 20 May 2019

Heikinheimo O (1915) Kaskiviljelyksen vaikutus Suomen metsiin. Summary: the effect of shifting cultivation on forests in Finland. Acta For Fenn 4(2):1-136. https://doi.org/10.14214/aff.7534

Heikinheimo O, Raatikainen M (1981) Ruutukoordinaattien ja paikannimien käyttö Suomessa. Summary: Grid references and names of localities in the recording of biological finds in Finland. Not Entomol 61(3):133-154

Helander AB (1949) Suomen metsätalouden historia. In: Finnish. Söderstrom, Porvoo, p 546

Henttonen HM, Nöjd P, Mäkinen H (2017) Environment-induced growth changes in the Finnish forests during 1971-2010 - an analysis based on National Forest Inventory. For Ecol Manag 386:22-36. https://doi.org/10.1016/j.foreco.2016.11.044

Henttonen HM, Nöjd P, Suvanto S, Heikkinen J, Mäkinen H (2019) Large trees have increased greatly in Finland during 1921-2013, but recent observations on old trees tell a different story. Ecol Indic 99:118-129. https://doi.org/10.1016/j.ecoli nd.2018.12.015

Hjerppe R (1989) The Finnish economy 1860-1985. Growth and Structural Change. Bank of Finland Publications. Studies on Finland's Economic Growth XIII, p 295

Hökkä H, Kaunisto S, Korhonen KT, Päivänen J, Reinikainen A, Tomppo E (2002) Suomen suometsät 1951-1994. In: Finnish. Metsätieteen aikakauskirja 2A/2002, pp 201-357. https://doi. org/10.14214/ma.6242

Hynynen J, Salminen H, Ahtikoski A, Huuskonen S, Ojansuu R, Siipilehto J, Lehtonen M, Eerikäinen K (2015) Long-term impacts of forest management on biomass supply and forest resource development: a scenario analysis for Finland. Eur J For Res 134:415431. https://doi.org/10.1007/s10342-014-0860-0

Hyvärinen E, Juslén A, Kemppainen E, Uddström A, Liukko U-M (eds.) (2019) The 2019 Red List of Finnish Species. Ympäristöministeriö \& Suomen ympäristökeskus. Helsinki p 704. http://hdl.handle.net/10138/299501

Ilvessalo Y (1927) Suomen metsät. Tulokset vuosina 1921-24 suoritetusta valtakunnan metsien arvioimisesta. Summary: The forests of Suomi (Finland). Results of the general survey of the forests of the country carried out during the years 1921-24. Comm Inst For Fenn 11:617

Jönsson MT, Fraver S, Jonsson BG (2009) Forest history and the development of old-growth characteristics in fragmented boreal forests. J Veg Sci 20:91-106. https://doi.org/10.111 1/j.1654-1103.2009.05394.x

Kalela O (1944) Suomen luonnonhistoriallisesta aluejaosta. In: Finnish. Memoranda soc pro fauna et flora Fenn 19, pp 151-165. http://hdl.handle.net/10138/37181

Kangas A, Astrup R, Breidenbach J, Fridman J, Gobakken T, Korhonen KT, Maltamo M, Nilsson M, Nord-Larsen T, Naesset E, Olsson H (2018) Remote sensing and forest inventories in Nordic countries_roadmap for the future. Scand J For Res 33(4):397-412. https://doi.org/10.1080/02827581.2017.1416666

Kauppi PE, Rautiainen A, Korhonen KT, Lehtonen A, Liski J, Nöjd P et al (2010) Changing stock of biomass carbon in a boreal forest over 93 years. For Ecol Manag 259(7):1239-1244. https://doi. org/10.1016/j.foreco.2009.07.044

Kauppi PE, Birdsey RA, Pan Y, Ihalainen A, Nöjd P, Lehtonen A (2015) Effects of land management on large trees and carbon stocks. Biogeoscience 12:855-862. https://doi.org/10.5194/ bg-12-855-2015

Kauppi PE, Sandström V, Lipponen A (2018) Forest resources of nations in relation to human well-being. PLoS ONE 13(5):e0196248. https://doi.org/10.1371/journal.pone.0196248

Keenan RJ, Reams GA, Achard F, de Freitas JV, Grainger A, Lindquist E (2015) Dynamics of global forest area: results from the FAO Global Forest Resources Assessment 2015. For Ecol Manag 352:9-20. https://doi.org/10.1016/j.foreco.2015.06.014

Köhl M, Lasco R, Cifuentes M, Jonsson Ö, Korhonen KT, Mundhenk P, Stinson G (2015) Changes in forest production, biomass and carbon: results from the 2015 UN Global Forest Resources Assessment. For Ecol Manag 352:21-34. https://doi.org/10.1016/j.forec o.2015.05.036

Korhonen KT, Ihalainen A, Ahola A, Heikkinen J, Henttonen HM, Hotanen JP et al (2017) Suomen metsät 2009-2013 ja niiden kehitys 1921-2013. In: Finnish. Luonnonvara- ja biotalouden tutkimus, 59/2017, p 86

Koskinen S, Martelin T, Notkola I-L, Notkola V, Pitkänen K (eds) (1994) Suomen väestö. In Finnish. Gaudeamus. Hämeenlinna. ISBN 951-662-599-1, p 339

Kuisma M (2006) Metsäteollisuuden maa. Suomi, metsät ja kansainvälinen järjestelmä. 2nd edition. In Finnish. Suomen historiallinen seura/Metsäteollisuus ry, Helsinki, p 633

Kuisma M (2013) Saha: Tarina Suomen modernisaatiosta ja ihmisistä jotka sen tekivät. In: Finnish. Siltala, Helsinki, p 235

Kuuluvainen RT, Tahvonen O, Aakala T (2012) Even-aged and unevenaged forest management in boreal Fennoscandia: a review. Ambio 41(7):720-737. https://doi.org/10.1007/s13280-012-0289-y

Laasasenaho J (1982) Taper curve and volume functions for pine, spruce and birch. Comm Inst For Fenn 108:1-74

Laurance W, Sayer J, Cassman K (2014) Agricultural expansion and its impacts on tropical nature. Trends Ecol Evol 29(2):107-116. https://doi.org/10.1016/j.tree.2013.12.001

Lawrence M, McRoberts RE, Tomppo E, Gschwantner T, Gabler K (2010) Comparisons of National Forest Inventories, pp. 19-32. In: Tomppo E, Gschwantner T, Lawrence M, McRoberts RE (eds) National Forest Inventories. Pathways for common reporting. Springer, Heidelberg, p 607. https://doi. org/10.1007/978-90-481-3233-1

Leikola M (1998) C. W. Gylden ja hänen oppikirjansa Suomen metsien hoidosta. Esipuhe C. W. Gyldenin teokseen”Suomalaisen metsänhoidon opas”. In: Finnish. Metsälehti Kustannus, pp 7-23

Lindeberg JW (1924) Über die Berechnung des Mittelfehlers des Resultates einer Linientaxierung. Acta For Fenn 25(5):1-22. https ://doi.org/10.14214/aff.7080

Lundqvist L (2017) Tamm review: selection system reduces long-term volume growth in Fennoscandic uneven-aged Norway spruce forests. For Ecol Manag 391:362-375. https://doi.org/10.1016/j.forec o.2017.02.011

MacDicken KG, Sola P, Hall J, Sabogal C, Tadoum M, de Wasseige C (2015) Global progress toward sustainable forest management. For Ecol Manag 352:47-56. https://doi.org/10.1016/j.forec o.2015.02.005

Mäntymaa E, Ovaskainen V, Juutinen A, Tyrväinen L (2018) Integrating nature-based tourism and forestry in private lands under heterogeneous visitor preferences for forest attributes. J Environ Plan Manag 61(4):724-746. https://doi.org/10.1080/09640 568.2017.1333408

Minkkinen K, Korhonen R, Savolainen I, Laine J (2002) Carbon balance and radiative forcing of Finnish peatlands 1900-2100 - the impact of forestry drainage. Glob Change Biol 8:785-799. https ://doi.org/10.1046/j.1365-2486.2002.00504.x

Myllyntaus T, Mattila T (2002) Decline or increase? The standing timber stock in Finland, 1800-1997. Ecol Econ 41:271-288 
Nilsson SG, Niklasson M, Hedin J, Aronsson G, Gutowski JM, Linder $P$ et al (2002) Densities of large living and dead trees in oldgrowth temperate and boreal forests. For Ecol Manag 161:189204. https://doi.org/10.1016/S0378-1127(01)00480-7

Official Statistics of Finland (2019) Greenhouse gases [e-publication]. ISSN 1797-6065. Statistics Finland, Helsinki [referred: 1.4.2019]. Access method: http://www.stat.fi/til/khki/index_en.html. Accessed 20 May 2019

Palo M, Lehto E (2012) Private or socialistic forestry? Forest transition in Finland vs. deforestation in the tropics. Dordrecht, Heidelberg, p 460. https://doi.org/10.1007/978-90-481-3896-8

Palo M, Uusivuori J (1999) Forest-based development in Finlanda unique success? In: Palo M, Uusivuori J (eds) World forests, society and environment. World Forests, vol I: 300-321. Kluwer, Dordrecht

Pan Y, Birdsey RA, Fang J, Houghton R, Kauppi PE, Kurz WA et al (2011) A large and persistent carbon sink in the world's forests. Science 333(6045):988-993. https://doi.org/10.1126/scien ce. 1201609

Saari E (1934) Puun käyttö Suomessa. Summary: Wood utilization in Suomi (Finland). Commun Inst For Fenn 14(1):1-248

Saket M, Branthomme A, Piazza M (2010) FAO NFMA—support to developing countries on National Forest Monitoring and Assessment, pp 583-594. In Tomppo E, Gschwantner T, Lawrence M, McRoberts RE (eds) National Forest Inventories. Pathways for common reporting. Springer, Heidelberg, p 607. https://doi. org/10.1007/978-90-481-3233-1

Sevola Y (1988) Puun käyttö Suomessa 1923-1985, pp. 107-127. In Finnish. In: Sevola Y (ed) Metsä, yritys, yhteiskunta. Metsäntutkimuslaitoksen tiedonantoja 288

Siiskonen H (2007) The conflict between traditional and scientific forest management in 20th century Finland. For Ecol Manag 249:125-133. https://doi.org/10.1016/j.foreco.2007.03.018

Statistics Finland (2018) Finland in Figures 2018. Edita Publishing. ISBN 978-952-244-604-6 (pdf) ISBN 978-952-244-603-9 (print). Finland In Figures Online Service stat.fi/finlandinfigures, p 53

Talousneuvosto (1985) Metsä 2000 -ohjelman pääraportti. In Finnish. Valtion painatuskeskus. Helsinki. ISBN 951-46-8662-4
Tasanen T (2004) Läksi puut ylenemähän. Metsien hoidon historia Suomesa keskiajalta metsäteollisuuden läpimurtoon 1870-luvulla. Summary: The History of Silviculture in Finland from the Mediaeval to the Breakthrough of Forest Industry in 1870s. Metsäntutkimuslaitoksen tiedonantoja 920, p 443

Tomppo E, Schadauer K, McRoberts RE, Gschwantner T, Gabler K, Ståhl G (2010) Introduction, pp 1-18. In: Tomppo E, Gschwantner T, Lawrence M, McRoberts RE (eds) National Forest Inventories. Pathways for common reporting. Springer, Heidelberg, p 607. https://doi.org/10.1007/978-90-481-3233-1

Tomppo E, Heikkinen J, Henttonen HM, Ihalainen A, Katila M, Mäkelä H, Tuomainen T, Vainikainen N (2011) Designing and conducting a forest inventory-case: 9th National Forest Inventory of Finland. Manag For Ecosyst 21:270. https://doi. org/10.1007/978-94-007-1652-0

Uusvaara O (1985) The quality and value of sawn goods from plantation-grown Scots pine. Commun Inst For Fenn 130:1-53

VanDerWal J, Falconi L, Januchowski S, Shoo L, Storlie C (2014) SDMTools: species distribution modelling tools: tools for processing data associated with species distribution modelling exercises. $\mathrm{R}$ package version 1.1-221. https://CRAN.R-project.org/packa ge $=$ SDMTools

Wallenius T (2011) Major decline in fires in coniferous forests-reconstructing the phenomenon and seeking for the cause. Silva Fenn 45(1):139-155. https://doi.org/10.14214/sf.36

Wright SJ, Muller-Landau HC, Condit R, Hubbell SP (2003) Gapdependent recruitment, realized vital rates, and size distributions of tropical trees. Ecology 84(12):3174-3185. https://doi. org/10.1890/02-0038

Publisher's Note Springer Nature remains neutral with regard to jurisdictional claims in published maps and institutional affiliations. 